\title{
ISOLATION, PURIFICATION, AND CHARACTERIZATION OF LIPASE FROM BACILLUS SP. FROM KITCHEN GREASE
}

\author{
JAIGANESH R, JAGANATHAN MK* \\ Department of Biotechnology, School of Bioengineering, SRM Institute of Science and Technology, Chennai, Tamil Nadu, India. \\ Email: jaganathan.mk@gmail.com
}

Received: 26 January 2018, Revised and Accepted: 07 March 2018

\begin{abstract}
Objective: The objective of this work was to isolation, purification and characterization of solvent tolerant lipase from Bacillus sp. The objective of this work was to isolation, purification and characterization of solvent tolerant lipase from Bacillus sp. from kitchen grease for a variety of applications including organic synthetic reactions and preparation of enantiomerically pure pharmaceuticals.
\end{abstract}

Methods: Lipase producing isolates were screened from kitchen grease on a selective medium rhodamine B olive oil agar, and tributyrin agar was used to screen the lipase and esterase producing an organism, respectively. The isolate identified using $16 \mathrm{~S}$ rDNA sequencing method and enzyme activity was quantitatively assayed. Lipase production was characterized in different conditions.

Results: The isolate showed highest lipase activity was which later was identified as Bacillus sp. using 16S rDNA sequencing method. The lipase was purified using ammonium sulfate precipitation. The isolate showed excellent tolerance to methanol, ethanol, acetonitrile, and moderate tolerance to butanol. The increased biomass concentration, maximum production, and activity were achieved at $37^{\circ} \mathrm{C}$ in $24 \mathrm{~h}$ incubation, then gradual reduction in production was observed. The maximum activity of lipase enzyme was obtained at pH between 6 and 9

Conclusion: The isolate produce solvent tolerance lipase enzyme and it can be a promising candidate of solvent tolerance lipase enzyme for variety of industrial applications.

Keywords: Lipase, Esterase, Bacillus sp., Purification, Biomass

(C) 2018 The Authors. Published by Innovare Academic Sciences Pvt Ltd. This is an open access article under the CC BY license (http://creativecommons. org/licenses/by/4. 0/) DOI: http://dx.doi.org/10.22159/ajpcr.2018.v11i6.24955

\section{INTRODUCTION}

Lipolytic enzymes (esterase [carboxyl ester hydrolases E.C. 3.1.1.1] and lipase [triacylglycerol acyl hydrolases E.C. 3.1.1.3]) are the cluster of enzyme used to hydrolyze the ester bond of triglycerides, diglycerides, and monoglycerides into fatty acids and glycerol [1]. Esterase and lipase are distinguished based on their substrates such as tributyrin and triolein, respectively. Carboxyl esterase catalyze the hydrolysis of acylglycerols with short chains of $<10$ carbon atoms, while lipases catalyze the hydrolyzes of acylglycerols with long chains of $\geq 10$ carbon atoms [2]. Lipolytic enzymes are excellent biocatalyst for various reactions include hydrolysis, esterification, transesterification, acidolysis, alkalosis, and synthesis of peptides [3].

Lipolytic enzymes are produced from several microorganisms including bacteria, yeast, fungi and actinomycetes. These microorganisms have been found in diverse habitats such as industrial wastes, vegetable oil processing factories, dairies, soil contaminated with oil, oil seeds, compost heaps, coal tips and hot springs. Among these, bacterial lipolytic enzymes are high in demand due to their specificity of the reaction, stereospecificity and less energy consumption than conventional method [5], also they are more economical, stable, easy to produce in large scale easy to manipulate the production either by genetically and environment [6]. Based on the sequence identity and biochemical properties bacterial lipolytic enzymes are classified into eight families (IVIII), in this true lipase family belongs to Family I, GDSL family belongs to Family II, hormone-sensitive lipase (HSL), and HSL family belongs to Family III and Family IV, respectively, and Families V-VIII [7]. Several lipolytic enzymes from Achromobacter sp., Alcaligenes sp., Arthrobacter sp., Pseudomonas sp., Staphylococcus sp., Bacillus sp., and Chromobacterium sp. have been isolated and characterized [8].

The bacterial lipolytic enzymes are mostly extracellular, and the production is greatly influenced by various factors such as carbon, nitrogen sources, $\mathrm{pH}$, temperature, aeration, and inoculums size [9]. In biotechnological application and organic chemistry, the most widely used enzyme is lipolytic enzymes, they widely used in dairy industries, detergent industries, processing of fats and oils, fine chemical production, textile industries, food processing, pharmaceuticals, synthesis of surfactants, polymers, paper manufacture, production of cosmetics, leather industries, and wastewater treatment [10-12].

\section{METHODS}

Isolation of lipolytic enzyme producing organism

Kitchen grease samples were collected from kitchen to isolate the lipolytic enzyme producing an organism. $1 \mathrm{~g}$ of kitchen grease sample was inoculated in $100 \mathrm{ml}$ of sterile distilled water and incubated at $37^{\circ} \mathrm{C}$ in rotary shaker incubator for $1 \mathrm{~h}$. To isolate the pure culture, $0.5 \mathrm{ml}$ of sample was inoculated on nutrient agar medium and incubated at $37^{\circ} \mathrm{C}$ for $24 \mathrm{~h}$. The isolated pure cultures were subjected to screen the lipolytic enzyme producing an organism.

\section{Screening of lipolytic enzyme producing organism}

The selective medium rhodamine B olive oil agar and tributyin agar were used to screen the lipase and esterase producing organism, respectively, in this the rhodamine $\mathrm{B}$ olive oil agar containing: $4 \mathrm{~g} / \mathrm{l}$ Nutrient broth, $2 \mathrm{~g} / \mathrm{l} \mathrm{NaCl}, 10 \mathrm{~g} / \mathrm{l}$ agar-agar, $5 \mathrm{ml}$ of olive oil, $10 \mathrm{~g} / \mathrm{l}$ rhodamine B solution, and $150 \mu \mathrm{l}$ tween 80 were used to screen the lipase producing organism and tributyrin agar containing: $5 \mathrm{~g} / \mathrm{l}$ Peptic digest of animal tissue, $3 \mathrm{~g} / \mathrm{l}$ yeast extract, $15 \mathrm{~g} / \mathrm{l}$ agar-agar, and $10 \mathrm{ml} / \mathrm{l}$ tributyrin. The isolated pure cultures were inoculated on both rhodamine $\mathrm{B}$ olive oil agar and tributyin agar and incubated at $37^{\circ} \mathrm{C}$ for $48 \mathrm{~h}$. After incubation, the orange color fluorescence producing organism in rhodamine B olive oil agar under ultraviolet (UV) light and clear zone producing organism in tributyin agar were isolated and identified by $16 \mathrm{~S}$ rRNA sequencing method. 
Identification of organism by $16 \mathrm{~S}$ rRNA sequencing method

Isolated bacteria were identified by various morphological and biochemical test on the basis of the criteria described in Bergey's Manual of Systematic Bacteriology. Then organism was further confirmed by $16 \mathrm{~S}$ rRNA sequencing. Genomic DNA is isolated from the bacteria, and the 16s rDNA was amplified, and the products were sequenced with Applied Biosystems 3130xl Genetic Analyzers. Phylogenetic trees were constructed using a Neighbor-Joining method using the MEGA 5.0 program [13].

\section{Estimation of lipase activity}

The lipase enzyme activity was determined using Para-nitro phenyl palmitate ( $p$-NPP) as a substrate by the method of Winkler and Stuckmann [14]. The reaction mixture contain: $2.5 \mathrm{ml}$ of p-nitrophenyl phosphate solution (mixture of solution A $[0.001 \mathrm{~g}$ pNPA in $1 \mathrm{ml}$ isopropanol] and solution B [0.01 g gum arabic, $0.02 \mathrm{~g}$ sodium deoxycholate, $50 \mu \mathrm{l}$ Triton X-100, and $9 \mathrm{ml}$ of $50 \mathrm{mM}$ Tris- $\mathrm{HCl}$ buffer, $\mathrm{pH}$ 8]) and $2.5 \mathrm{ml} 50 \mathrm{mM}$ Tris-HCl buffer ( $\mathrm{pH}$ 8).The $1 \mathrm{ml}$ of cell-free supernatant was added to the reaction mixture incubated for $30 \mathrm{~min}$ at $37^{\circ} \mathrm{C}$. During this period, the lipase enzyme hydrolyze ester bond and released free para-nitrophenol was estimated using spectrophotometer at $410 \mathrm{~nm}$. One unit of enzyme corresponds to the $1 \mu \mathrm{mol}$ of released para-nitrophenol per minute under the standard assay conditions.

\section{Partial purification of lipase enzyme by ammonium sulfate}

The partial purification of crude lipase enzyme was achieved by ammonium sulfate precipitate method described by Green and Hughen [15]. The culture broth was collected and centrifuged at $10,000 \mathrm{rpm}$ for $15 \mathrm{~min}$ in $4^{\circ} \mathrm{C}$, and cell-free supernatant containing extracellular enzyme was fractionated with ammonium sulfate to get $60 \%-80 \%$ saturation with continuous stirring for overnight in $4^{\circ} \mathrm{C}$. Followed by the fractions were centrifuge at 15,000 rpm for $20 \mathrm{~min}$ in $4^{\circ} \mathrm{C}$. Then, precipitates were collected and resuspended in $50 \mathrm{Mm}$ TrisHCL buffer ( $\mathrm{pH} 8$ ) and the enzyme dialyzed there times against buffer for overnight [16].
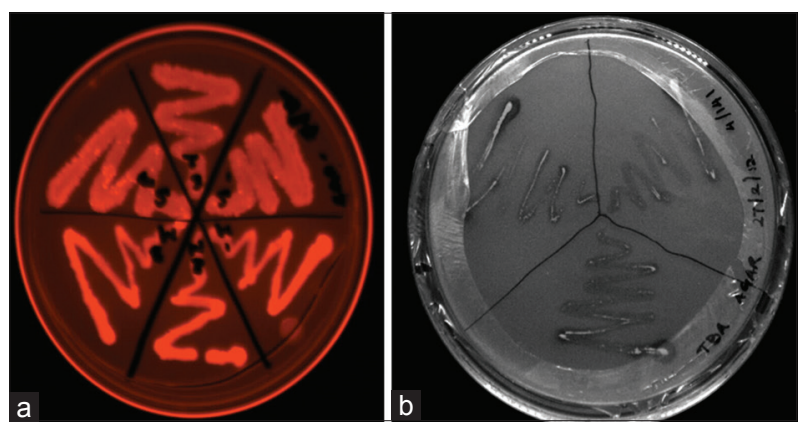

Fig 1: a) Orange fluorescence indicates the Esterase enzyme production in Rhodamine B Olive Oil Agar. b) Zone of clearance indicates the Lipase enzyme production
Optimization of lipase enzyme production

Effect of organic solvent on growth

To determine the organic solvent tolerance of lipase-producing bacteria, the different concentrations $(0.5 \%, 1 \%, 2 \%$, and $4 \%)$ of methanol, ethanol, butanol, and acetonitrile were supplemented with nutrient broth growth media and to prevent evaporation of the organic solvent all the flask were plugged with a rubber stopper. The culture flask without solvent was taken as control. Then, all flasks were incubated in rotary shaker $37^{\circ} \mathrm{C}$ for $48 \mathrm{~h}$, followed by growth of solvent tolerance was measured and compared with respect to control.

\section{Effect of optimum temperature and incubation period on enzyme production}

To determine the optimum temperature and incubation period on enzyme production, the lipase producing organism was inoculated in nutrient broth growth media and was incubated rotary shaker incubator at various temperatures such as $20^{\circ} \mathrm{C}, 37^{\circ} \mathrm{C}, 50^{\circ} \mathrm{C}, 55^{\circ} \mathrm{C}$, and $60^{\circ} \mathrm{C}$ and every $6 \mathrm{~h}(6,18,24,30$, and 36$)$ the enzyme production was analyzed.

\section{Effect of temperature on growth}

The analyze the various temperature $\left(20^{\circ} \mathrm{C}, 37^{\circ} \mathrm{C}, 50^{\circ} \mathrm{C}, 55^{\circ} \mathrm{C}\right.$, and $60^{\circ} \mathrm{C}$ ) effect on the lipase producing bacterial growth, organism was inoculated in nutrient broth and incubated at a different temperature in a rotary shaker incubator. After incubation, the biomass concentration was analyzed regularly at every $6 \mathrm{~h}$ intervals up to $36 \mathrm{~h}$ using spectrophotometer at $600 \mathrm{~nm}$ [17]. The carrying out the assay in triplicate and average of the experiment carried out 3 times, and the average values were taken.

\section{Effect of $p H$ on enzyme activity}

The lipase producing organisms were subjected to grow in various $\mathrm{pH}$ to determine the effect of $\mathrm{pH}$ on enzyme activity. The tributyrin agar before the incubation of lipase-producing organism adjusted with the various $\mathrm{pH}(3,4,5,6,7,8,9$, and 10$)$ and incubated at $37^{\circ} \mathrm{C}$ in rotary shaker incubator for $48 \mathrm{~h}$. Then, the culture broth was collected, centrifuged at 10,000 rpm for $20 \mathrm{~min}$ and in the cell-free supernatant, enzyme activity was analyzed. The enzyme activity assay repeated for 3 times and mean value was taken.

\section{Effect of temperature on enzyme activity}

To optimize the temperature on enzyme activity, the lipase producing organisms were inoculated in tributyrin agar and incubated under various temperatures $\left(20^{\circ} \mathrm{C}, 40^{\circ} \mathrm{C}, 60^{\circ} \mathrm{C}\right.$, and $\left.80^{\circ} \mathrm{C}\right)$ in rotary shaker incubator for $48 \mathrm{~h}$. Then, the culture broth was collected, centrifuged at $10,000 \mathrm{rpm}$ for $20 \mathrm{~min}$ and in the cell-free supernatant enzyme activity was analyzed. The enzyme activity assay repeated for 3 times and mean value was taken.

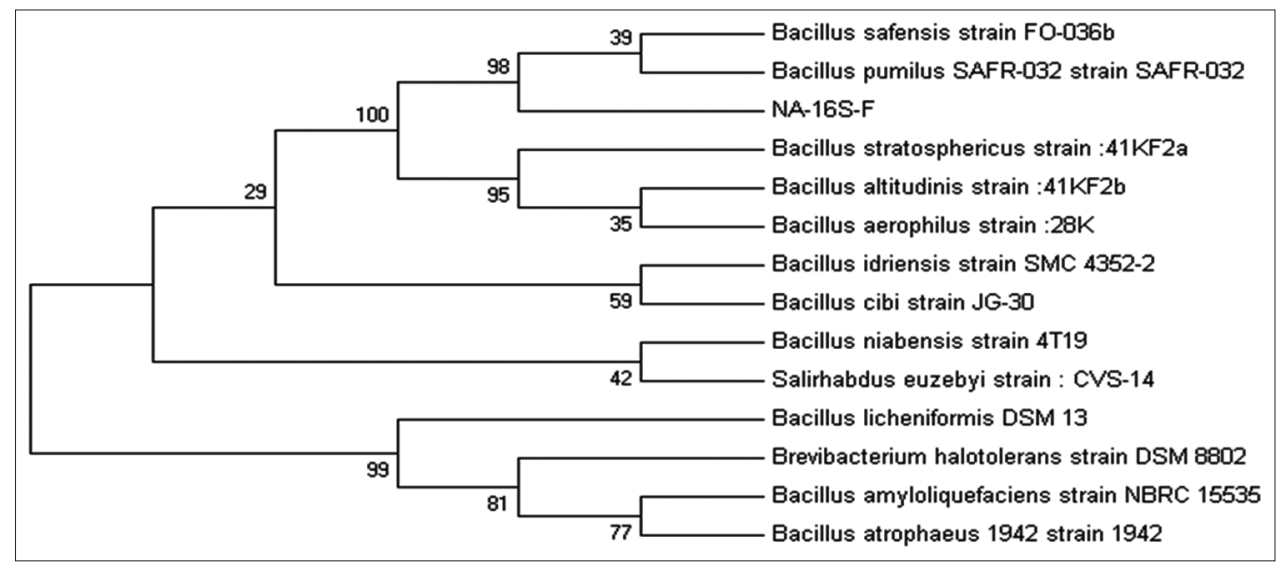

Fig 2: The phylogenetic tree of Bacillus MM03 and other close homology microbes 


\section{RESULTS AND DISCUSSION}

Screening of lipolytic enzyme producing organism

Among the various strain isolated from kitchen grease samples, the lipolytic enzyme producing bacterial isolates were screened using rhodamine B olive oil agar and tributyrin agar. In this, Esterase enzyme producing organism showed the orange color fluorescence in rhodamine B olive oil agar when illuminating under UV light, and lipase enzyme producing organism showed clear zone around the colonies in tributyrin agar [Fig. 1]. Then, the potential lipolytic enzyme producing strain was selected based on the size of zone clearance and intensity of fluorescence and the isolated bacterial strain was identified by $16 \mathrm{~S}$ rRNA sequencing method. Kanimozhi et al., also isolated the lipase producing organism from oil mill waste and oil refinery waste contaminated site, respectively [18]

Identification of organism by $16 \mathrm{~S}$ rRNA sequencing method

Among the various lipase producing organism, the bacteria which showed maximum lipase production was selected, identified by morphological character, various biochemical characters, and 16S rRNA. Then, the sequence was compared with sequences available in the GenBank using a BLAST search. Their sequence relationships were analyzed using the software MEGA 5.0 to understand the evolutionary distance of sequenced bacteria by constructing the phylogenic tree and identified the bacteria as Bacillus MMO3 [Fig. 2].

\section{Ammonium sulfate purification of lipase enzyme}

The lipase produced from Bacillus sp. purified by ammonium sulfate method, the purification process was summarized in Table 1 . Increase of enzyme specific activity observed in $60 \%-80 \%$ of ammonium sulfate precipitation followed by dialysis. The purification process resulted in 2.8-fold purification and a final yield of $80 \%$ of the enzyme with a specific activity of $940 \mathrm{U} / \mathrm{mg}$. Abigor et al., (2002)[19] also reported that the lipase enzyme produced from Jatropha curcas purified with $80 \%$ ammonium sulfate precipitation achieved a 2.8 -fold increase in the relative activity of the lipase in the supernatant.

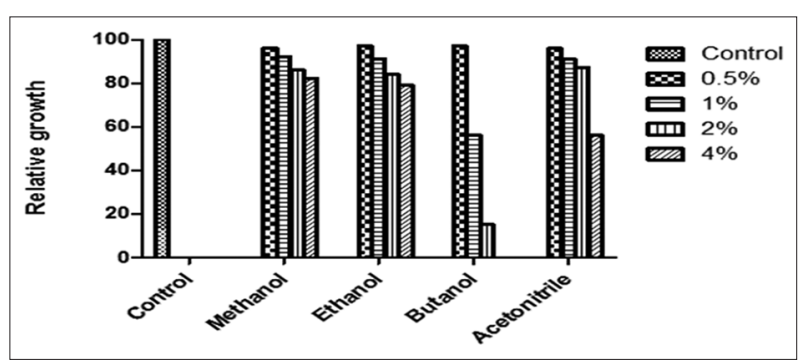

Fig 3: Effect of organic solvent on Bacillus MM03 growth

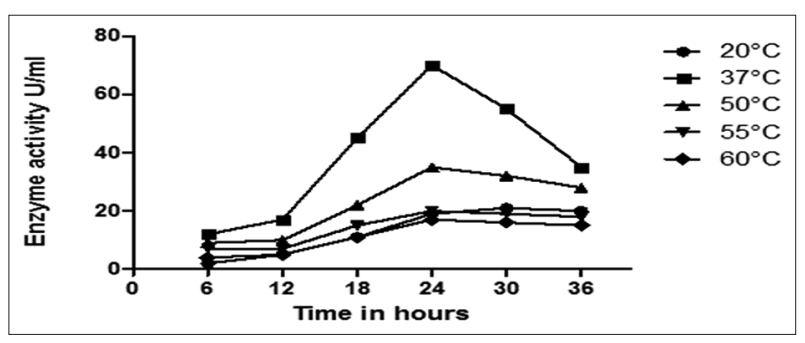

Fig 4: Effect of temperature and incubation period on enzyme production
Effect of organic solvent on growth

Ogino et al. $[20,21]$ reported that most of the organic solvent tolerant organism are producing highly stable lipase enzyme. In this study, the Bacillus MM03 shown excellent tolerance to methanol, ethanol, and acetonitrile and moderate tolerance to butanol. Above $75 \%$ of growth was observed even in $4 \%$ of methanol, ethanol, $0.5 \%$ of butanol, and $2 \%$ of acetonitrile (Fig. 3). Kumar et al. [22] reported that the Grampositive bacteria originated from the marine environment such as Rhodococcus, Arthrobacter, and Bacillus showed excellent tolerance to organic solvents.

Effect of optimum temperature and incubation period on enzyme production

The effect of optimum temperature on enzyme production was estimated at every $6 \mathrm{~h}$ till $36 \mathrm{~h}$. The maximum production was achieved at $37^{\circ} \mathrm{C}$ in $24-\mathrm{h}$ incubation, then a gradual reduction in production was observed (Fig. 4). Abdou [23] also reported that the maximum lipase production was found during $30^{\circ} \mathrm{C}-40^{\circ} \mathrm{C}$ by Serratia sp. isolated from raw milk samples, and also our result correlated with the production of lipase by Micrococcus roseus [24].

\section{Effect of temperature on growths}

To optimize the effect of temperature on growth, organism was inoculated in the growth medium and incubated under $20^{\circ} \mathrm{C}, 37^{\circ} \mathrm{C}$, $50^{\circ} \mathrm{C}, 55^{\circ} \mathrm{C}$, and $60^{\circ} \mathrm{C}$. Among the various temperatures, the increased biomass concentration was observed at $37^{\circ} \mathrm{C}$ (Fig. 5). Mohan et al. [25] also reported that the maximum biomass concentration was obtained at $37^{\circ} \mathrm{C}$ for the lipase producing Bacillus sp.

\section{Effect of pH on enzyme activity}

The $\mathrm{pH}$ of the medium is most important for the production of enzyme activity. In this study, the maximum activity of lipase enzyme was obtained at $\mathrm{pH}$ between 6 and 9 (Fig. 6). This result is correlated with the solid-state fermentation of lipase enzyme activity produced at $\mathrm{pH}$ between 5 and 6 by Rhizopus homothallicus $[26,27]$. Similar results were reported, where lipase production from marine actinomycetes

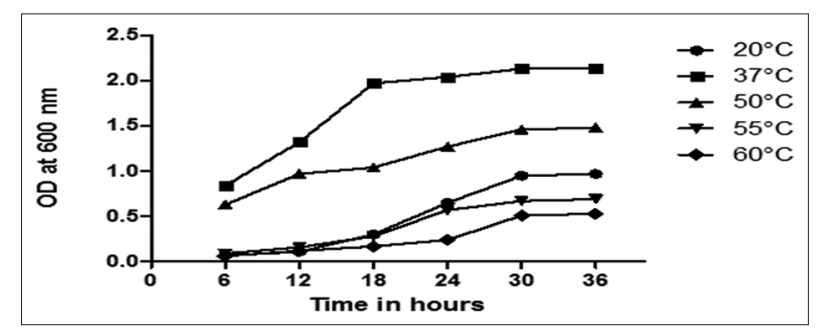

Fig 5: Effect of temperature on growth

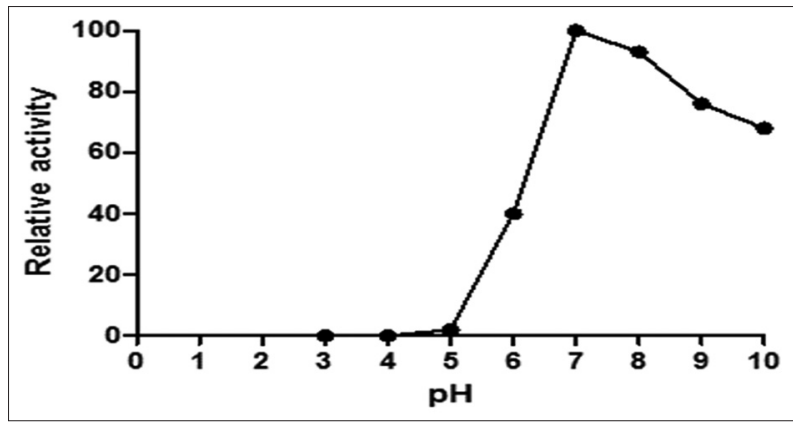

Fig 6: Effect of pH on enzyme activity

Table 1: Purification process of lipase from Bacillus MMO3

\begin{tabular}{lllllll}
\hline Step & Volume (ml) & Total protein (mg) & Total activity (U) & Specific activity (U/mg) & Purification (fold) & Yield (\%) \\
\hline Culture supernatant & 100 & 8.3 & 2787 & 335.8 & 1 & 100 \\
Ammonium sulfate & 7 & 2.4 & 2256 & 940 & 2.8 & 80 \\
\hline
\end{tabular}




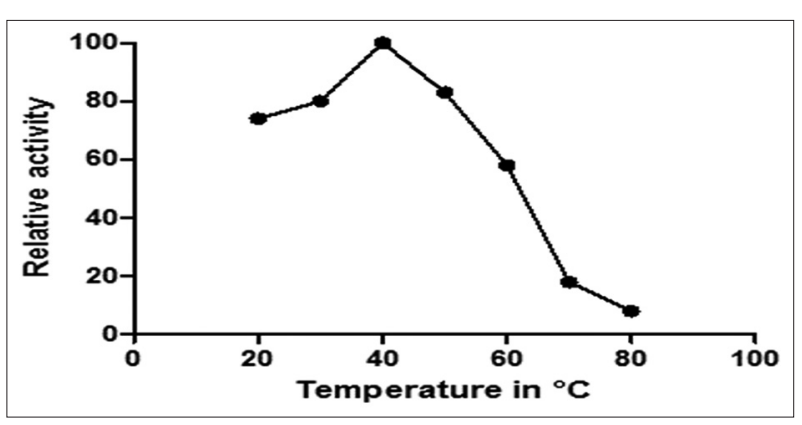

Fig 7: Effect of temperature on enzyme activity

was maximum at pH 6 and the bacteria Pseudomonas gessardii has optimum lipase production at $\mathrm{pH} 7.0[28,29]$.

\section{Effect of temperature on enzyme activity}

The maximum activity of lipase enzyme at different temperature was analyzed, in this, the maximum activity was achieved at $37^{\circ} \mathrm{C}$, and it was slowly reduced, in $80^{\circ} \mathrm{C}$ the production got ceased [Fig. 7]. Similar result was reported that the maximum lipase production was at $37^{\circ} \mathrm{C}$ by Pseudomonas xinjiangensis [30].

\section{CONCLUSION}

In the present study, we isolated solvent tolerance producing bacteria from the kitchen grease. The highest lipase producer in the supernatant was selected, and further characterized by 16S RNA sequencing and was identified as Bacillus spp. The results of this study indicate that Bacillus sp. is valuable as a source of lipase isolated from kitchen grease. Lipase produced by Bacillus sp. shows maximum enzyme production after $24 \mathrm{~h}$ and good solvent tolerance. Therefore, Bacillus sp. can be a promising candidate of solvent tolerance lipase enzyme for a variety of industrial applications.

\section{AUTHORS CONTRIBUTIONS}

JMK and JGR equally contributed to study design, conduct of experiments, data collection manuscript preparation, critical revision, and finalization of the manuscript. Both the authors agree with the content of the manuscript.

\section{CONFLICT OF INTEREST}

There is no conflict of interest.

\section{REFERENCES}

1. Sakai Y, Hayatsu M, Hayano K. Use of tween 20 as a substrate for assay of lipase activity in soils. Soil Sci Plant Nutr 2002;48:729-34.

2. Jaeger KE, Dijkstra BW, Reetz MT. Bacterial biocatalysts: Molecular biology, three-dimensional structures, and biotechnological applications of lipases. Annu Rev Microbiol 1999;53:315-51.

3. Benjamin S, Pandey A. Mixed-solid substrate fermentation. A novel process for enhanced lipase production by Candida rugosa. Acta Biotechnol 1998;18:315-24.

4. Vakhlu J, Kour A. Yeast lipases: Enzyme purification, biochemical properties and gene cloning. Electron J Biotechnol 2006;9:69-85.

5. Saxena RK, Ghosh PK, Gupta R, Davidson WS, Bradoo S, Gulati R. Microbial lipases: Potential biocatalysts for the future industry. Curr Sci 1999;77:101-15.

6. Hasan F, Shah AA, Hameed A. Industrial applications of microbial lipases. Enzyme Microb Technol 2006;39:235-51.

7. Arpigny JL, Jaeger KE. Bacterial lipolytic enzymes: Classification and properties. Biochem J 1999;343 Pt 1:177-83.

8. Aravindan R, Anbumathi P, Viruthagiri T. Lipase applications in food industry. Indian J Biotechnol 2007;6:141-58

9. Gupta N, Mehra G, Gupta R. A glycerol-inducible thermostable lipase from Bacillus sp.: Medium optimization by a plackett-burman design and by response surface methodology. Can J Microbiol 2004;50:361-8.

10. Park H, Lee KS, Chi YM, Jeong SW. Effects of methanol on the catalytic properties of porcine pancreatic lipase. J Microbiol Biotechnol 2005; 15:296-1.

11. Thota P, Bhogavalli PK, Vallem PR, Venkateswar S. Studies on optimization of extracellular lipase from potential fungal strain (s) isolated from oil contaminated soil. J Microbiol Biotechnol Res 2012;2:418-25.

12. Jain MK. Methods in enzymology volume 284. Lipases: Part A, biotechnology edited by B. Rubin (Lipomed) and E. A. Dennis (university of California-San Diego). Academic Press: San Diego. 1997. Xxxi. J Am Chem Soc 1998;120:5354.

13. Tamura K, Peterson D, Peterson N, Stecher G, Nei M, Kumar S, et al. MEGA5: Molecular evolutionary genetics analysis using maximum likelihood, evolutionary distance, and maximum parsimony methods. Mol Biol Evol 2011;28:2731-9.

14. Winkler UK, Stuckmann M. Glycogen, hyaluronate, and some other polysaccharides greatly enhance the formation of exolipase by Serratia marcescens. J Bacteriol 1979;138:663-70.

15. Green AA, Hughes WL. [10] Protein fractionation on the basis of solubility in aqueous solutions of salts and organic solvents. Methods Enzymol 1955;1:67-90.

16. Shu $\mathrm{CH}, \mathrm{Xu}$ CJ, Lin GC. Purification and partial characterization of a lipase from Antrodia cinnamomea. Process Biochem 2006;41:734-38.

17. Henriette C, Zinebi S, Aumaitre MF, Petitdemange E, Petitdemange H. Protease and lipase production by a strain of Serratia marcescens (532 S). J Ind Microbiol 1993;12:129-35.

18. Kanimozhi1 K, Devairrakam EJ, Jegadeeshkumar D. Production and optimization of lipase from Bacillus subtilis. Int J 2011;2:6-10.

19. Abigor RD, Uadia PO, Foglia TA, Haas MJ, Scott K, and Savary BJ. Partial purification and properties of lipase from germinating seeds of Jatropha curcas L., J. Am. Oil Chem. Soc 2002;79(11):1123-126.

20. Ogino H, Miyamoto K, Ishikawa H. Organic-solvent-tolerant bacterium which secretes organic-solvent-stable lipolytic enzyme. Appl Environ Microbiol 1994;60:3884-6.

21. Ogino H, Miyamoto K, Yasuda M, Ishimi K, Ishikawa H. Growth of organic solvent-tolerant Pseudomonas aeruginosa LST-03 in the presence of various organic solvents and production of lipolytic enzyme in the presence of cyclohexane. Biochem Eng J 1999;4:1-6.

22. Kumar S, Ramesh R, Bhosle NB, Sardesai S, Sheshshayee MS. Natural isotopic composition of nitrogen in suspended particulate matter in the bay of bengal. Biogeosciences 2004;1:63-70.

23. Abdou AM. Purification and partial characterization of Psychrotrophic serratia marcescens lipase. J Dairy Sci 2003;86:127-32.

24. Joseph B, Upadhyaya S, Ramteke P. Production of cold-active bacterial lipases through semisolid state fermentation using oil cakes. Enzyme Res 2011;2011:796407.

25. Mohan TS, Palavesam A, Immanvel G. Isolation and characterization of lipase-producing Bacillus strains from oil mill waste. Afr J Biotechnol 2008; $7: 2728-35$

26. Rodriguez JA, Mateos JC, Nungaray J, Gonzalez V, Bhagnagar T, Roussos $\mathrm{S}$, et al. Improving lipase production by nutrient source modification using Rhizopus homothallicus cultured in solid state fermentation. Process Biochem. 2006;41(11):2264-2269.

27. Kumar KD, Usha KY, Satyanarayana SV, Sailaja V. Characterization of partially purified lipase from Saccharomyces cerevisiae. Int J Pharm Pharm Sci 2014;6:514-17.

28. Suji CM, Priya RS, Sivaraj R. Optimization of lipase production from different agroindustrial wastes by marine actinomycetes. Int J Pharm Pharm Sci 2014;6:292-4.

29. Veerapagu M, Narayanan AS, Ponmurugan K, Jeya KR. Screening selection identification production and optimization bacterial lipase from oil spilled soil. Asian J Pharm Clin Res 2013;6 Suppl 3:62-7.

30. Lomthaisong K, Buranarom Z, Niamsup Z. Investigation of isolated lipase producing bacteria from oil-contaminated soil with proteomic analysis of its proteins responsive to lipase inducer. J Biol Sci 2012;12:161-7. 